\title{
Uptake and Recycling of Soluble Reactive Phosphorus by Marine Microplankton
}

\author{
William G. Harrison \\ Marine Ecology Laboratory, Bedford Institute of Oceanography, Box 1006, Dartmouth, Nova Scotia, Canada B2Y 4A2
}

\begin{abstract}
Simultaneous measurements of soluble reactive phosphorus (SRP) uptake and regeneration (using isotope-dilution methodology) by natural marine microplankton populations are described for coastal and oceanic waters. Seasonal fluctuations in SRP fluxes in Bedford Basin (Canada) were characterized by high uptake and low regeneration rates during spring and fall bloom periods and higher relative (compared with uptake) and absolute regeneration rates during summer. On an annual basis, SRP regeneration by microplankton could meet ca. $50 \%$ of the phosphorus requirements for planktonic production. In oceanic waters microplankton were also important in recycling SRP, providing $>60 \%$ of the P-requirements for growth in the Peruvian upwelling region and in the Eastern Tropical Pacific Ocean. At times, $>100 \%$ of uptake requirements may be supplied by microplankton in Arctic waters. Size-fractionation studies showed that SRP uptake and regeneration were generally partitioned by particle size with relatively greater regeneration rates associated with organisms larger than $1 \mu \mathrm{m}$ in size.
\end{abstract}

\section{INTRODUCTION}

It has long been known that marine primary production in coastal and oceanic waters is largely supported by in situ nutrient recycling processes (e. g. Harrison, 1980). However, detailed quantitative studies of the sites and biological sources of nutrient remineralization have only recently been made, since the introduction of radioactive and stable isotope tracer techniques.

Most marine work has focussed on the cycling of nitrogen since it is considered the element most likely limiting primary production in coastal (Ryther and Dunstan, 1971) and oceanic waters (Goldman et al., 1979; Perry and Eppley, 1981). Recent studies employing isotope-dilution techniques, for example, have successfully measured nitrogen $\left(\mathrm{NH}_{4}{ }^{+}\right)$remineralization in natural microplankton populations and have shown their importance in supplying nitrogen for primary production (e. g. Harrison, 1978; Caperon et al., 1979; Glibert, 1982). Unfortunately, however, stable isotope studies of nitrogen cycling often suffer from methodological problems. Substrate enrichment, i. e. the requirement for large, non-'tracer' level additions of labelled substrate, and difficulties in measuring low ambient substrate concentrations are considered among the most significant problems which may seri- ously affect the reliability of results (Harrison, 1982).

Phosphorus, on the other hand, may be less subject to such analytical problems because of its availability in carrier-free radioisotopic form and because techniques for measuring extremely low concentrations have been developed (e. g. Strickland and Parson, 1972; Cescon and Scarazzato, 1973). Furthermore, because of the apparent close interrelationship between nitrogen and phosphorus in the biological production cycle (e. g. Redfield et al., 1963) and particularly in oceanic waters (Perry and Eppley, 1981), studies of the dynamics of phosphorus cycling are clearly relevant to the more general question of how nutrient regeneration processes regulate primary production rate.

Relatively few tracer studies of phosphorus cycling have been done in marine waters when compared with the extensive work in lakes (Nalewajko and Lean, 1980). Most published studies have been confined to coastal or estuarine environments (Pomeroy, 1961; Taft et al., 1975; Harrison et al., 1977; Kuenzler et al., 1979) and, where P-recycling has been measured, have often only emphasized the production of organic-P compounds (Johannes, 1964a; Keunzler, 1970; Lemasson and Pages, 1981). With few exceptions (e. g. Johannes, $1964 \mathrm{~b})$, inorganic-P regeneration has been determined 
only for large (generally $>100 \mu \mathrm{m}$ ) planktonic organisms.

In this paper, I describe measurements of uptake and recycling of soluble reactive phosphorus (SRP) ${ }^{*}$ by natural marine microplankton " populations in coastal and oceanic waters. Particular emphasis has been placed on an assessment of regional and temporal variations in the importance of microplankton regeneration in meeting population phosphorus requirements for primary production.

\section{METHODS}

\section{Sampling}

Most measurements were made during a seasonal study of primary production and nutrient fluxes in a coastal embayment of Nova Scotia (Bedford Basin) from February 1978 to February 1979 (Irwin et al., 1982). Samples were collected approximately twice monthly from 5 meters and the $1 \%$ light penetration depth (varying from 10 to $25 \mathrm{~m}$ ) using $301-1$ PVC Niskin bottles.

Samples were also collected during November, 1977 off the Northern Coast of Peru, $9^{\circ} \mathrm{S}$ Lat., $79^{\circ} \mathrm{W}$ Long. (Harrison et al., 1982b), in August, 1980 in Lancaster Sound, Eastern Canadian Arctic, ca. $74^{\circ} \mathrm{N}$ Lat, $90^{\circ} \mathrm{W}$ Long, and in April, 1981 in the Eastern Tropical Pacific, ca. $10^{\circ} \mathrm{N}$ Lat, $95^{\circ} \mathrm{W}$ Long. (Longhurst, 1981). Off Peru, surface and $1 \%$ light penetration depths (derived from secchi readings) were sampled. Multiple depths (4 to 5) within the euphotic zone were sampled during the Arctic and tropical Pacific cruises.

\section{Analytical}

Particulate matter, concentrated on Reeve Angel $984 \mathrm{H}$ or Whatman GF/F glass fiber filters, was analyzed for chlorophyll a (Holm-Hansen et al., 1965), organic carbon (Sharp, 1974), and organic phosphorus (U-V oxidation, Perry and Eppley, 1981). Soluble reactive phosphorus (SRP) was determined on filtrates

\footnotetext{
- Because the molybdenum blue method has been found to overestimate orthophosphate $\left(\mathrm{PO}_{4}{ }^{-}\right)$on occasion (e. g. Rigler, 1968), SRP has been considered a more appropriate designation. However, the extent of this problem in ocean waters has not been experimentally determined, but will be considered unimportant here

- In this study, microplankton are operationally defined as all organisms (microzooplankton, phytoplankton, bacteria) caught during sample collection (bottle casts) and transferred intact to incubation bottles. Although samples were not prescreened, large zooplankton were never observed on sample filters
}

using the isobutanol extraction method described in Strickland and Parsons (1972).

\section{Tracer Experiments}

Water samples $(200 \mathrm{ml})$ were dispensed into replicate $250 \mathrm{ml}$ transparent glass bottles for carbon and phosphorus tracer experiments. Primary production rates were determined using the ${ }^{14} \mathrm{C}$-method (Strickland and Parsons, 1972). Each sample was inoculated with ca. $5 \mu \mathrm{Ci} \mathrm{NaH}{ }^{14} \mathrm{CO}_{3}$ and incubated for 4 to $24 \mathrm{~h}$ in 'simulated' in situ deck boxes, attenuated with perforated nickel screens, and cooled with near surface flowing seawater. Five-m depth samples (Bedford Basin study) were incubated at approximately $50 \%$ of incident radiation; $1 \%$ light level samples were incubated at that light level. Experiments were terminated by filtration of particulates onto glass fiber filters which were subsequently rinsed with filtered seawater and Iater analyzed for radioactivity by scintillation spectrometry. Time-zero filtrations were used for ${ }^{14} \mathrm{C}$ adsorption correction.

Phosphorus (SRP) uptake and regeneration rates were determined using ${ }^{33} \mathrm{P}$ (carrier-free phosphoric acid) as a tracer. Experimental protocol and incubation conditions were similar to primary production measurements. Approximately $2 \mu \mathrm{Ci}{ }^{33} \mathrm{P}$ were added to replicate $400 \mathrm{ml}$ samples, $200 \mathrm{ml}$ aliquots of which were immediately filtered, with filters and filtrates frozen for later analysis. The remaining $200 \mathrm{ml}$ samples were incubated as described above. In the laboratory, filtrates were analyzed for SRP concentration and radioactivity (scintillation counting) by the isobutanolextraction method (see above). Precision of this analytical step was good, yielding an average coefficient of variation (C.V.) of 5 to $6 \%$ for replicate determinations. Filters also were analyzed for radioactivity and for all analyses $\left({ }^{14} \mathrm{C},{ }^{33} \mathrm{P}\right)$, Aquasol $\mathrm{II}^{\mathrm{R}}$ was used as a counting fluor.

SRP regeneration rates were determined by 'isotope dilution' and calculated using the equations of Blackburn (1979) and Caperon et al. (1979). In simplified form:

$$
r=\frac{\ln \left(R_{0} / R_{t}\right)}{\ln \left(S_{0} / S_{t}\right) t} \cdot\left(S_{0}-S_{t}\right)
$$

where $r=S R P$ regeneration rate $\left(m g\right.$-at $\left.m^{-3} t^{-1}\right) ; R_{o}$, $\mathrm{R}_{\mathrm{t}}=$ specific activity of SRP (DPM/mg-at) at times 0 and $t ; S_{o}, S_{t}=S R P$ concentrations ( $\mathrm{mg}$-at $\mathrm{m}^{-3}$ ) at times 0 and $t$. $R$ values were corrected for isotope decay and alcohol extraction efficiency. This equation assumes (1) no recycling of the tracer $\left({ }^{33} \mathrm{P}\right)$, and (2) a constant regeneration rate over the incubation period. Linearity in uptake and regeneration measurements from time- 


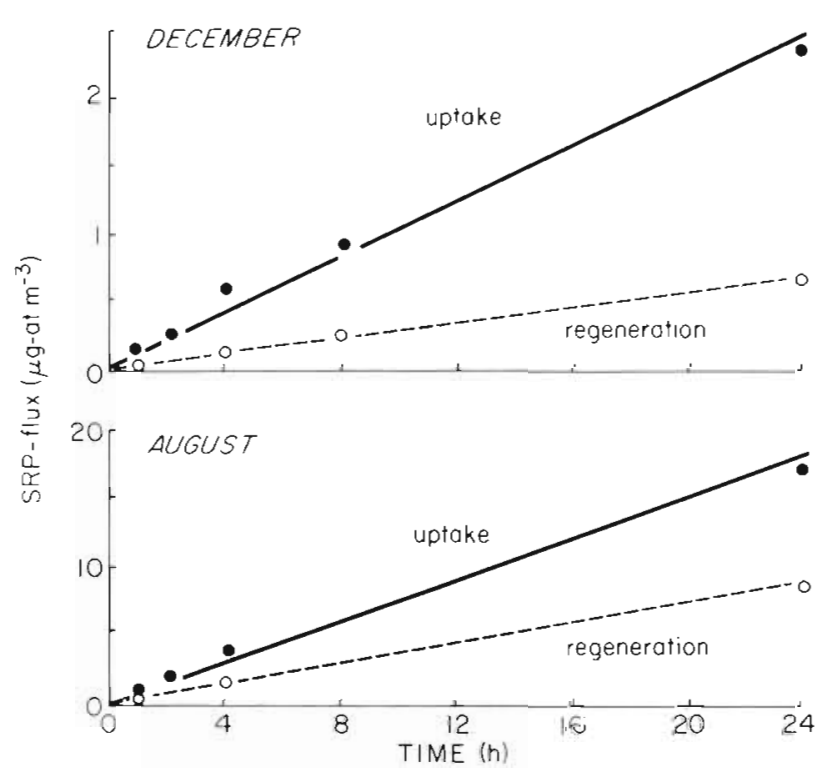

Fig. 1. Time-course of SRP uptake and regeneration from near-surface waters of Bedford Basin. Samples incubated (starting $10.00 \mathrm{~h}$, local time) in continuous, subdued light and maintained at ambient temperature $\left(6^{\circ} \mathrm{C}\right.$, December; $14^{\circ} \mathrm{C}$, August)

course studies suggested that both assumptions were probably valid for up to 24 h incubations (Fig. 1). In all experiments, only a small portion of the added isotope was incorporated into the particulate matter $(\bar{x}=20 \%$, Bedford Basin study) in $24 \mathrm{~h}$. Non-linear uptake kinetics resulting from rapid SRP turnover (and isotopic recycling), commonly seen in freshwater and estuarine environments (Nalewajko and Lean, 1980), was not evident in my experiments.

SRP uptake rates were calculated from ${ }^{33} \mathrm{P}$ incorporation into the particulate matter:

$$
u=\frac{\left(D_{P M}-D P M_{o}\right)}{\bar{R} \cdot t}
$$

where $\mathrm{u}=\mathrm{SRP}$ uptake rate (mg-at $\left.\mathrm{m}^{-3} \mathrm{t}^{-1}\right) ; \mathrm{DPM}_{\mathrm{t}}$ $\mathrm{DPM}_{0}=$ radioactivity of the particulate matter at times 0 and $t ; \bar{R}=$ specific activity of SRP (DPM/mg-at) corrected for 'isotope-dilution', where $\bar{R}=\frac{R_{o}}{k_{t}}\left(1-e^{-k t}\right)$ and $\mathrm{R}_{\mathrm{o}}=$ initial SRP specific activity; $k_{\mathrm{t}}=$ rate constant describing the time-dependant change in $R$ (Glibert et al., 1982). Uptake rates corrected for 'isotope-dilution' generally deviated less than $10 \%$ from uncorrected estimates (i. e. where substrate specific activity is assumed constant, $\bar{R}=R_{0}$ ). Chemically poisoned controls $\left(\mathrm{HgCl}_{2}\right.$, formalin) showed no significant increase in particulate radioactivity (above 'time-zero') nor measurable changes in SRP specific activity over time $(24 \mathrm{~h})$.

\section{RESULTS}

\section{Seasonal Study in Coastal Waters}

Temporal variations in phytoplankton biomass and production in Bedford Basin were dominated by 2 pronounced 'blooms' in 1978; 1 in spring and 1 in fall (Fig. 2). However, relatively high biomass and production rates persisted throughout the summer months. SRP fluxes also showed a peak during spring but values generally increased from early summer to an a n n u l maximum in fall (Fig. 3b, Table 1). P-fluxes were low in winter when aigal biomass and productivity were low (Fig. 2) and when nutrient concentrations were maximal (Fig. 3a, Table 1). SRP uptake and regeneration rates covaried although uptake almost always exceeded regeneration rates. Differences between uptake and regeneration were greatest during bloom periods (Fig. 3c). P-fluxes at $5 \mathrm{~m}$ were generally higher than at the $1 \%$ light level (Table 2). SRP uptake rate, normalized to primary production rate, also showed a seasonal pattern. Highest C : P assimilation ratios (atomic basis) were observed during the 2 bloom periods (Fig. 4). Organic Carbon (POC): organic
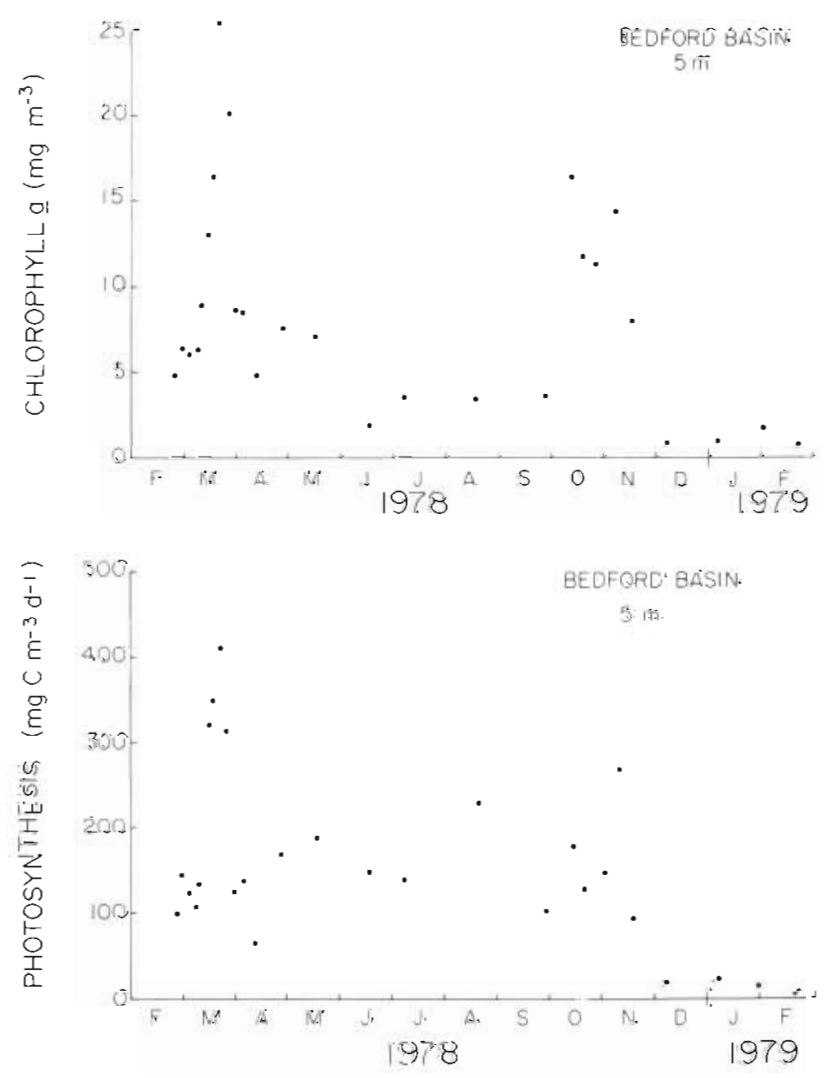

Fig. 2. Annual cycle of phytoplankton biomass (chl a) and primary production in Bedford Basin, February 1978 to February, 1979 


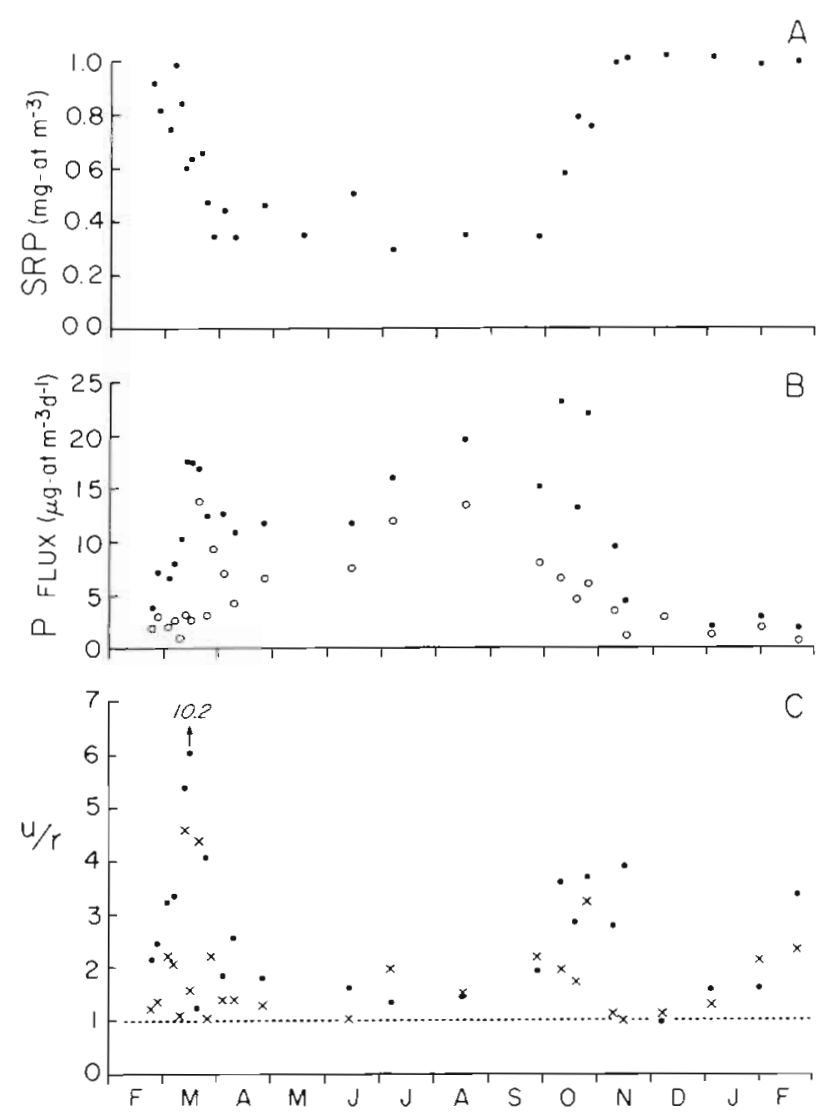

Fig. 3. Annual cycle of SRP concentrations and fluxes, Bedford Basin, February 1978 to February 1979. Closed circles in Panel B: SRP uptake rate; open circles: regeneration rate. Closed circles in Panel C: $\mathrm{u}: \mathrm{I}$ ratio of $5 \mathrm{~m}$ samples; $(\mathrm{x})=1 \%$ light level samples

phosphorus (POP) compositional ratios of the particulate matter, on the other hand, showed a peak only during the spring bloom. Throughout most of the year, C: P particulate ratios were relatively constant at ca. 200 (Fig. 5, Table 1). Ratios of particulate P:Chl

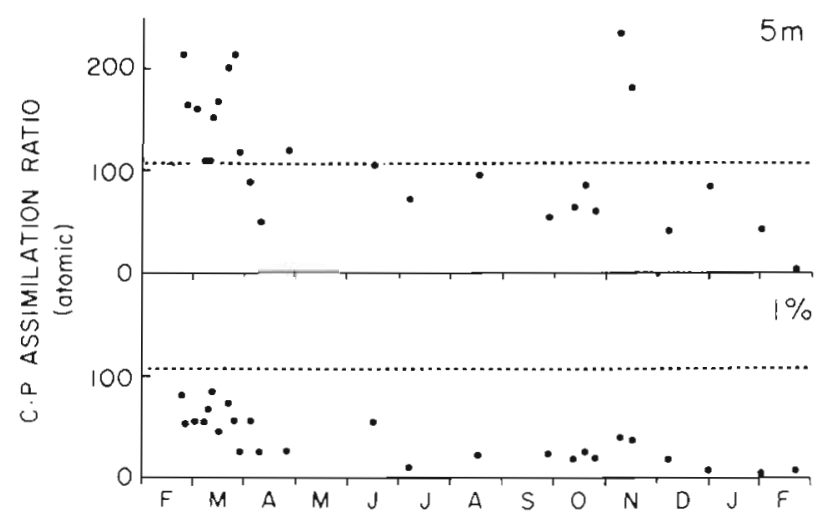

Fig. 4. Annual cycle of $\mathrm{C}: \mathrm{P}$ assimilation ratios (atomic), Bedford Basin, February 1978 to February 1979. Dotted lines: 'Redfield Ratio' (Redfield et al., 1963) (weight basis) were low during both bloom periods $(\overline{\mathrm{x}}=0.3$ and 0.7 for spring and fall, respectively) and 2 to 3 times higher during summer and winter. No significant difference between depths $(5 \mathrm{~m}, 1 \%$ light depth) was noted for any of the particulate ratios.

SRP turnover rates (flux/POP, in units of $t^{-1}$ ) were highest during spring (uptake) and summer (regeneration) and lowest during the fall bloom period (Table 1). Despite low absolute P-fluxes during winter, turnover rates were relatively high because of low POP levels. SRP regeneration rates represented 10 to $100 \%$ of the P-demand for uptake with greatest proportions occurring in summer and winter (Tables 1 and 2). Regeneration rates decreased relatively less than uptake at depth and as a consequence, represented a greater proportion of the P-demand at the $1 \%$ light level (Table 2). SRP turnover times (SRP/uptake) were shortest during summer $(\overline{\mathrm{x}}=2.8 \mathrm{~d}$ ) and increased to greater than $40 \mathrm{~d}$ on the average during winter (Table 1). Decreased P-uptake and increased SRP concentrations at depth resulted in higher turnover times at the $1 \%$ light level (Table 2).

\section{Oceanic Studies}

SRP fluxes measured in upwelling waters off the Northern Coast of Peru were similar in magnitude and vertical pattern to those from the Bedford Basin study (Table 2). Uptake and regeneration rates covaried; uptake generally exceeded regeneration. Surface fluxes were usually greater than rates measured at the $1 \%$ light penetration depth and at both depths, SRP regeneration accounted for greater than $60 \%$ on the average of the P-demand for uptake.

On single occasions in the Canadian Arctic and the Eastern Tropical Pacific, depth profiles (within the euphotic zone) of SRP uptake and regeneration were measured. In the Arctic, the vertical profiles of uptake and regeneration rates were similar in form, however, regeneration exceeded uptake at most depths. Highest fluxes were associated with the subsurface chlorophyll

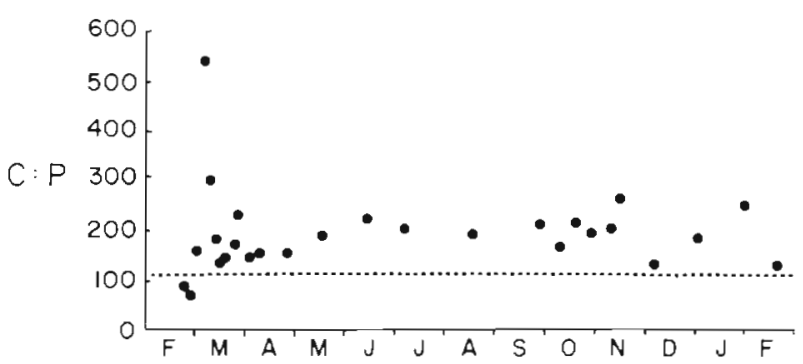

Fig. 5. Annual cycle of $\mathrm{C}: \mathrm{P}$ ratio of the particulate matter (atomic), Bedford Basin, February 1978 to February 1979. Dotted line: 'Redfield Ratio' 
Table 1. Soluble reactive phosphorus concentrations, fluxes and phytoplankton biomass for Bedford Basin (February 1978 to February 1979), summarized by season. Means and ranges (brackets) for $5 \mathrm{~m}$ depth

\begin{tabular}{|c|c|c|c|c|c|}
\hline & Parameter & $\begin{array}{l}\text { Spring bloom } \\
\qquad(\mathrm{n}=8)\end{array}$ & $\begin{array}{l}\text { Summer } \\
(\mathrm{n}=5)\end{array}$ & $\begin{array}{l}\text { Fall bloom } \\
\qquad(\mathrm{n}=5)\end{array}$ & $\begin{array}{l}\text { Winter } \\
(\mathrm{n}=4)\end{array}$ \\
\hline \multirow[t]{6}{*}{ I } & $\begin{array}{l}\text { Particulates } \\
\left(\mathrm{mg} \mathrm{m}^{-3}\right)\end{array}$ & & & & \\
\hline & POC & $\begin{array}{c}250 \\
(133-393)\end{array}$ & $\begin{array}{c}394 \\
(289-534)\end{array}$ & $\begin{array}{c}611 \\
(385-829)\end{array}$ & $\begin{array}{c}75 \\
(50-94)\end{array}$ \\
\hline & POP & $\begin{array}{c}3.7 \\
(0.9-6.8)\end{array}$ & $\begin{array}{c}5.6 \\
(3.7-7.1)\end{array}$ & $\begin{array}{c}8.1 \\
(4.7-10.2)\end{array}$ & $\begin{array}{c}1.2 \\
(0.9-1.4)\end{array}$ \\
\hline & $\mathrm{Chl}$ & $\begin{array}{c}13.0 \\
(6.0-25.6)\end{array}$ & $\begin{array}{c}5.0 \\
(1.8-8.4)\end{array}$ & $\begin{array}{c}12.2 \\
(7.9-16.2)\end{array}$ & $\begin{array}{c}0.9 \\
(0.5-1.5)\end{array}$ \\
\hline & $\mathrm{C}: \mathrm{P}$ (atomic) & 222 & 183 & 199 & 181 \\
\hline & P : Chl (weight) & 0.3 & 1.1 & 0.7 & 1.4 \\
\hline II & $\begin{array}{l}\text { SRP } \\
\left(\mathrm{mg}-\mathrm{at} \mathrm{m}^{-3}\right)\end{array}$ & $\begin{array}{c}0.66 \\
(0.34-0.99)\end{array}$ & $\begin{array}{c}0.39 \\
(0.29-0.46)\end{array}$ & $\begin{array}{c}0.83 \\
(0.58-1.04)\end{array}$ & $\begin{array}{c}1.05 \\
(0.98-1.17)\end{array}$ \\
\hline \multirow[t]{6}{*}{ III } & $\begin{array}{l}\text { P-flux } \\
\left.\text { (mg-at } m^{-3} d^{-1}\right)\end{array}$ & & & & \\
\hline & $\mathrm{u}$ & $\begin{array}{c}0.12 \\
(0.06-0.18)\end{array}$ & $\begin{array}{c}0.14 \\
(0.11-0.20)\end{array}$ & $\begin{array}{c}0.14 \\
(0.04-0.23)\end{array}$ & $\begin{array}{c}0.03 \\
(0.02-0.04)\end{array}$ \\
\hline & I & $\begin{array}{c}0.05 \\
(0.01-0.14)\end{array}$ & $\begin{array}{c}0.08 \\
(0.04-0.13)\end{array}$ & $\begin{array}{c}0.04 \\
(0.01-0.06)\end{array}$ & $\begin{array}{c}0.02 \\
(0.01-0.03)\end{array}$ \\
\hline & $\mathrm{u}: \mathrm{POP}$ (atomic) & 1.02 & 0.77 & 0.55 & 0.65 \\
\hline & r:POP (atomic) & 0.39 & 0.46 & 0.17 & 0.40 \\
\hline & SRP : u (atomic) & 5.4 & 2.8 & 5.8 & 40.4 \\
\hline
\end{tabular}

maximum layer (Fig. 6). Unfortunately, no additional depth profiles were made to determine if the exceptionally high regeneration rates observed in the area of the subsurface chlorophyll maxima were a common feature of these waters. At 2 other stations, however, surface samples showed low SRP uptake $(<20 \mu \mathrm{g}$-at $\mathrm{m}^{-3} \mathrm{~d}^{-1}$ ) and no measurable regeneration.

The depth profile of SRP fluxes in the Tropical Pacific revealed a different pattern (Fig. 7). Uptake and regeneration fluxes generally covaried but were highest near the sea surface, i. e. highest fluxes were not associated with the chlorophyll maximum. In this case, uptake exceeded regeneration at most depths, the difference being greatest near surface.

\section{DISCUSSION}

\section{Seasonal Variations in SRP Fluxes}

Uptake and regeneration of SRP strongly covaried seasonally in Bedford Basin (Fig. 8) with highest fluxes occurring during summer when ambient SRP levels were lowest. However, seasonally related fluctuations in uptake: regeneration ( $u: r)$ ratios were also apparent; high ratios occurred during bloom development and lowest ratios occurred following the blooms and during summer. Elevated regeneration fluxes (relative to uptake) were particularly apparent during the spring bloom decline (Fig. 3). This seasonal pattern in

Table 2. Mean values and ranges for SRP uptake, regeneration and turnover times $\left(T_{t}\right)$ for Bedford Basin and Peru upwelling studies

\begin{tabular}{|c|c|c|c|c|c|c|}
\hline Location & $z$ & $\begin{array}{l}\text { SRP uptake (u) } \\
\qquad(\mathrm{mg}-\mathrm{c}\end{array}$ & $\begin{array}{l}\text { SRP regeneration ( } \mathrm{r}) \\
\mathrm{m}^{-3} \mathrm{~d}^{-1} \text { ) }\end{array}$ & $\begin{array}{l}r / u \\
(\%)\end{array}$ & $\begin{array}{l}T_{t} \\
\text { (d) }\end{array}$ & \# obs \\
\hline \multicolumn{7}{|l|}{ Bedford Basin } \\
\hline & $5 \mathrm{~m}$ & $\begin{array}{c}0.111 \\
(0.019-0.232)\end{array}$ & $\begin{array}{c}0.049 \\
(0.006-0.138)\end{array}$ & $\begin{array}{c}45 \\
(10-103)\end{array}$ & $\begin{array}{c}12.3 \\
(1.8-51.6)\end{array}$ & 26 \\
\hline & $1 \%$ & $\begin{array}{c}0.060 \\
(0.014-0.138)\end{array}$ & $\begin{array}{c}0.036 \\
(0.006-0.087)\end{array}$ & $\begin{array}{c}64 \\
(23-100)\end{array}$ & $\begin{array}{c}26.2 \\
(3.2-133.8)\end{array}$ & 26 \\
\hline \multirow[t]{2}{*}{ Peru } & $100 \%$ & $\begin{array}{c}0.167 \\
(0.038-0.312)\end{array}$ & $\begin{array}{c}0.116 \\
(0.032-0.218)\end{array}$ & $\begin{array}{c}68 \\
(40-93)\end{array}$ & $\begin{array}{c}7.0 \\
(1.7-22.4)\end{array}$ & 11 \\
\hline & $1 \%$ & $\begin{array}{c}0.109 \\
(0.028-0.250)\end{array}$ & $\begin{array}{c}0.069 \\
(0.017-0.148)\end{array}$ & $\begin{array}{c}65 \\
(53-83)\end{array}$ & $\begin{array}{c}35.0 \\
(9.1-69.7)\end{array}$ & 6 \\
\hline
\end{tabular}




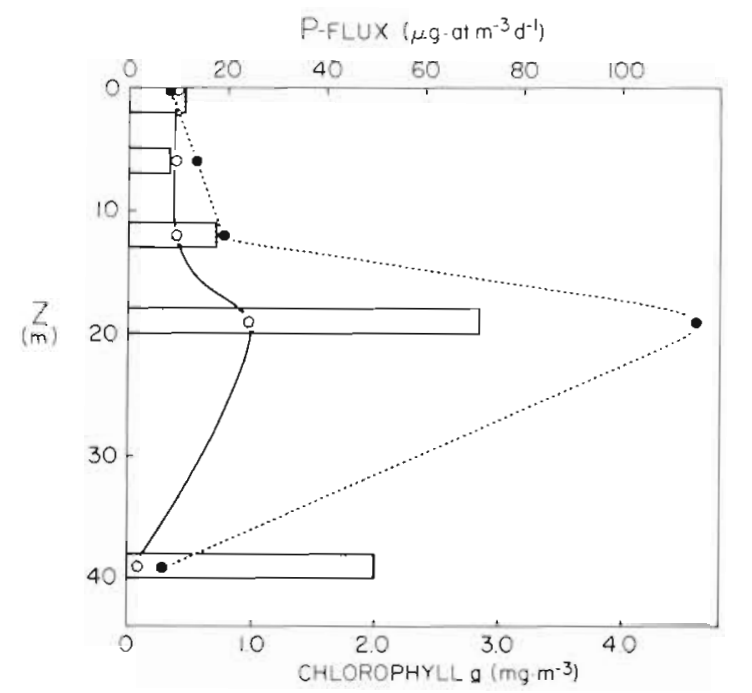

Fig. 6. Depth profile of SRP uptake and regeneration in relation to phytoplankton biomass (chl a), Eastern Canadian Arctic, $74^{\circ} \mathrm{N}$ Lat., $90^{\circ} \mathrm{W}$ Long., 15 August 1980. Open circles: uptake; closed circles: regeneration; bars: chlorophyll a

P-fluxes is typical for coastal waters (Ketchum and Corwin, 1965; Duerden, 1973; Taft et al., 1975; Kuenzler et al., 1979). Furthermore, Taft et al. (1975) and Kuenzler et al. (1979) have also noted a strong correlation between SRP uptake and recycling.

Kuenzler et al. (1979), for example, observed that SRP recycling (efflux, in their terminology) averaged greater than $70 \%$ of uptake rates during spring and early summer in the Pamlico River Estuary. However, contrary to our results they observed non-linear uptake kinetics and noted $u: r$ ratios decreased (i.e. 'net' uptake decreased) as absolute flux rates increased. Based on the similarity between these and results from cultured freshwater algae (Nalewajko and Lean, 1978),

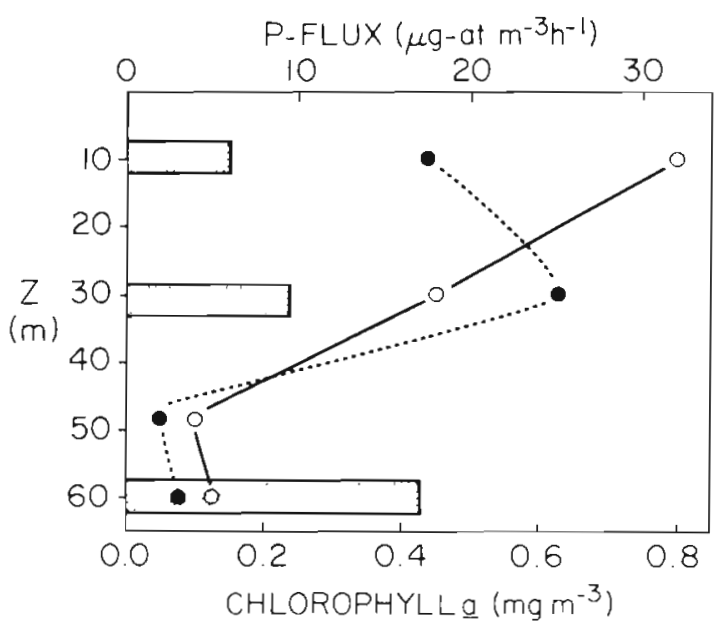

Fig. 7. Depth profile of SRP uptake and regeneration in relation to phytoplankton biomass (chl a), Eastern Tropical Pacific, $10^{\circ} \mathrm{N}$ Lat., $95^{\circ} \mathrm{W}$ Long., 4 April 1981. Symbols as in Fig. 6 they suggested that a substantial quantity of the recycled SRP was released (or exchanged) directly by the phytoplankton. Exchange of SRP between external medium and phytoplankton internal pools has frequently been suggested for freshwater (e.g. Lean, $1973 a$, b) and estuarine environments (Pomeroy, 1961; Taft et al., 1975; Kuenzler et al., 1979) when algal biomass (and P-demand) greatly exceeds substrate (SRP) concentrations, i. e. under severely P-limited growth. Such conditions are commonly characterized by highly non-linear uptake over time, resulting in rapid (hours or less) isotopic equilibration, and anomalously low $\mathrm{C}: \mathrm{P}$ assimilation ratios (Taft et al., 1975; Kuenzler et al., 1979). The reason for high Pefflux at a time when demand is greatest is still unclear (Nalewajko and Lean, 1980). Under these conditions where the dominant uptake and regeneration fluxes are mediated directly by the same particulate pool(s), the model and assumptions used in my study would not be valid (see 'Methods', Equations 1 and 2).

Studies of phosphorus utilization in cultured oceanic phytoplankton, on the other hand, have failed to demonstrate SRP efflux (e. g. Perry, 1976; Burmaster and Chisholm, 1979), nor has it been apparent in many field investigations (e. g. Perry, 1976; Harrison et al., 1977). This may be due in part to a general lack of severe P-limitation in marine waters. Results from the present study, i. e. linear SRP uptake rates (Fig. 1; see also Duerden, 1973) slow SRP turnover (Tables 1 and 2) and $\mathrm{C}: \mathrm{P}$ assimilation ratios consistent with particulate composition ratios (Figs. 4 and 5; see also Goldman et al., 1979), provide indirect evidence that phytoplank-

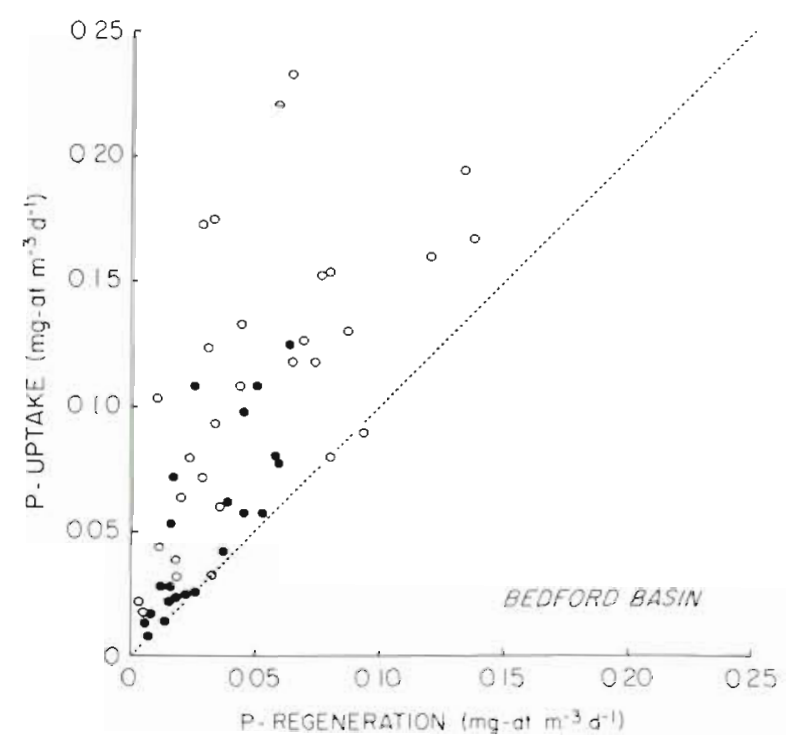

Fig. 8. Relationship between SRP uptake and regeneration rates, Bedford Basin 1978-1979 study. Open circles: $5 \mathrm{~m}$ samples; closed circles: $1 \%$ light level samples. Dotted line: $1: 1$ correspondence 
ton contributed little directly to the SRP regeneration rates observed. Furthermore, they support the assumption implicit in the model (Equations 1 and 2) that uptake and regeneration involve different particulate pools in the marine microplankton, at least over the time span of an incubation experiment ( $24 \mathrm{~h}$ )

No attempts were made at the time of sampling to ascertain directly the organisms responsible for the measured SRP recycling; however, highest regeneration rates coincided with summer abundance peaks in microplanktonic grazers, i. e. ciliates and flagellated protozoans (G. Cota, unpubl.). The high u:r ratios observed during the spring and fall blooms probably reflected the relative absence of such grazers. Nevertheless, SRP regeneration by microplankton satisfied at least $50 \%$ of the annual P-requirements $(\overline{\mathrm{x}}=60 \%$ in summer $)$ for production in this coastal embayment.

\section{Oceanic Studies}

Taken together, the SRP fluxes measured in Peru, Arctic and Tropical Pacific waters also showed a strong correspondence between uptake and regeneration (Fig. 9). However, the u i r ratio remained fairly con-

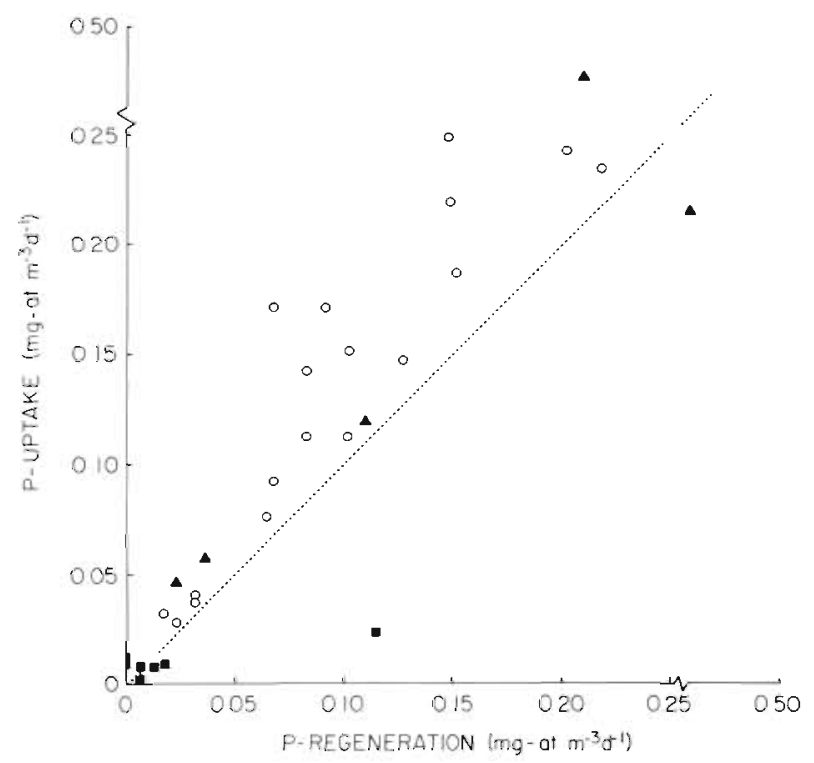

Fig. 9. Relationship between SRP uptake and regeneration rates, Peru (open circles), Arctic (closed squares) and Tropical Pacific (closed triangles) stations. Dotted line $1: 1$ correspondence

stant over the range of fluxes encountered, i. e. u : I did not appear to increase when fluxes were highest, as observed in the Bedford Basin study. In Peru, micro- plankton contributed $60 \%$ or more of the P-required for uptake with fluxes generally being greatest in the shallow samples (Table 2). Although few measurements were made in Tropical oceanic waters, the pattern was similar, i.e. uptake and recycling fluxes covaried and were highest near the surface (Fig. 7). For this station, regeneration rates exceeded $50 \%$ of production needs when integrated over the euphotic zone $(0-60 \mathrm{~m})$.

It has been suggested that the importance of microplankton in nutrient recycling is greatest in oligotrophic ocean waters (Jackson, 1980) and generally decreases shoreward as productivity level increases (Harrison, 1980). With all data combined, this pattern was not immediately evident in my study (Fig. 9). However, on a regional basis the relationship appeared to hold, i. e. in Peru surface waters the contribution of microplankton P-regeneration to uptake requirements varied inversely with primary production rate (Fig. 10)

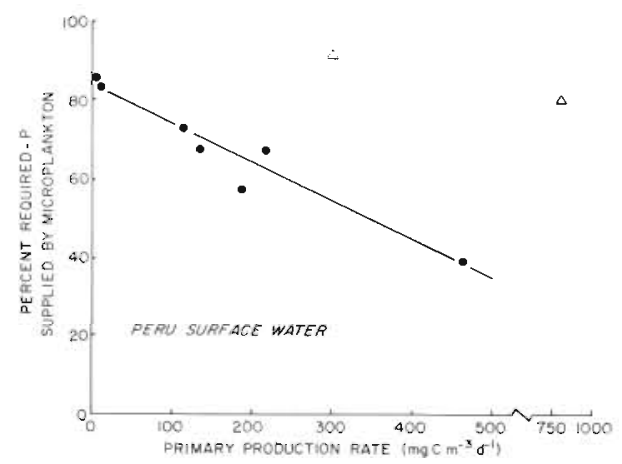

Fig. 10. Relationship between P-requirement supplied by microplankton ( $\mathrm{r} / \mathrm{u}, \%)$ and primary production rate, Peru surface waters. Triangles: stations dominated by the 'red-tide' ciliate Mesodinium rubrum

On 2 occasions, in coastal (Peru) and oceanic (Tropical Pacific) waters, phytoplankton biomass (chl a), primary productivity and SRP fluxes were size-fractionated (Table 3). Results from the Peru experiment suggested that only a small fraction $(<10 \%)$ of the SRP fluxes and primary production were attributable to micro-organisms less than $1 \mu \mathrm{m}$ : most activity was associated with organisms $>35 \mu \mathrm{m}$ (ca. $75 \%$ ). Interestingly, the contribution of SRP regeneration to the 1 to $35 \mu \mathrm{m}$ size class was 2 -fold greater than that of P-uptake and primary production rate. Microscopic inspection revealed an abundant phytoplankton assemblage dominated by large chain-forming diatoms (Harrison et al., 1982b). 
Table 3 . Size-fractionation ' studies of phytoplankton biomass, chl a (mg $\left.\mathrm{m}^{-3}\right)$, productivity (mg C m $\left.{ }^{-3} \mathrm{~d}^{-1}\right)$ and SRP fluxes ( $\mu \mathrm{g}^{-\mathrm{at}}$ $\mathrm{m}^{-3} \mathrm{~d}^{-1}$ ) from Peru and Eastern Tropical Pacific

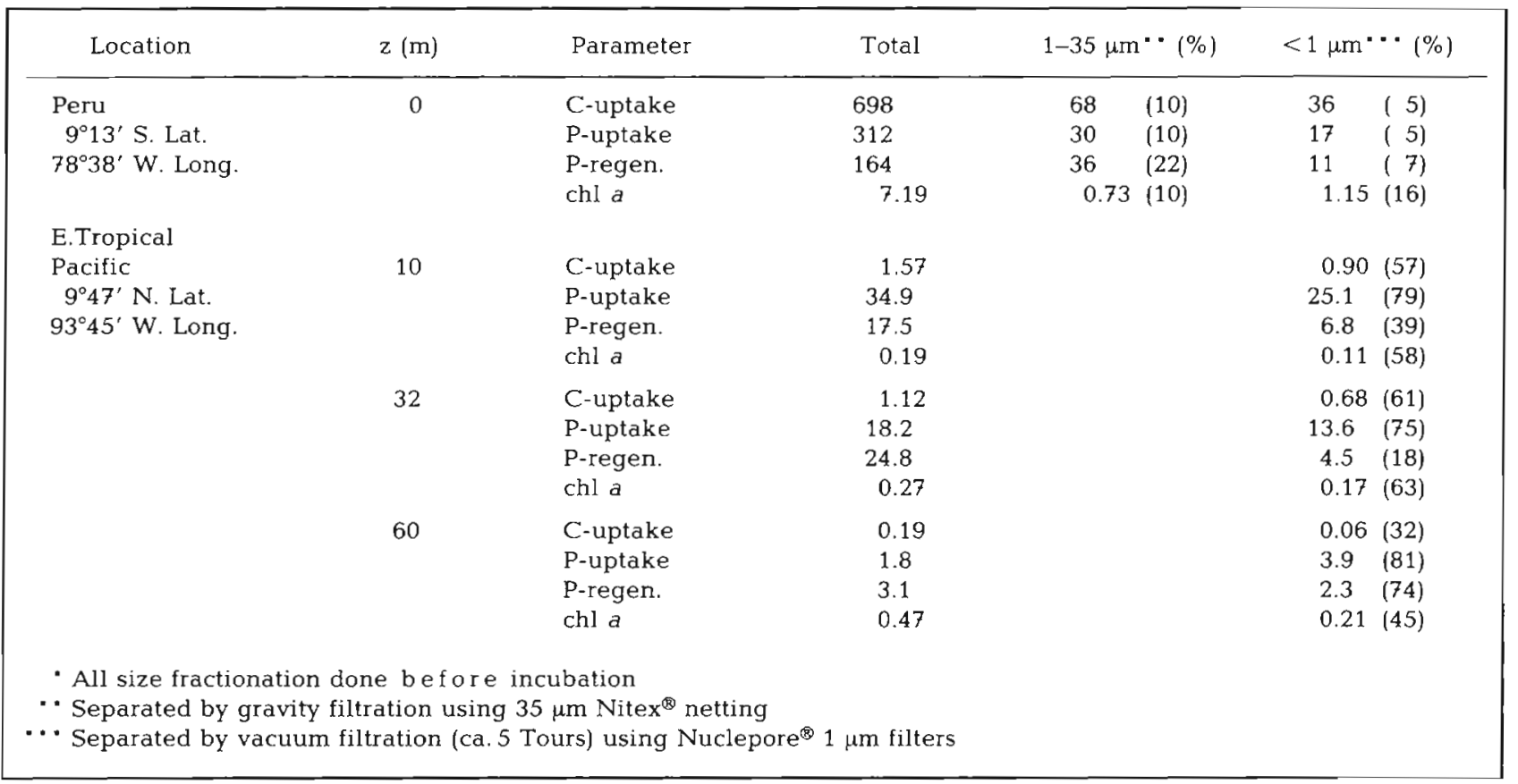

The size distribution of SRP fluxes and primary production were markedly different in the tropical oceanic samples. Here, more than $50 \%$ of the primary production and P-uptake were associated with $<1 \mu \mathrm{m}$ particles. However, in the 10 and $32 \mathrm{~m}$ samples most of the $\mathrm{SRP}$ regeneration was associated with the $>1 \mu \mathrm{m}$ fraction. Only in the deep $(60 \mathrm{~m})$ sample were the distributions of SRP uptake and regeneration similar. In contrast to Peru, these waters were dominated by photoautotraophic cyanobacteria during the time of sampling (Subba Rao, 1982). Although generalization based on so few experiments would be premature, differences were noted in the size-class partitioning of SRP uptake and regeneration at both sites and suggested that regeneration may be relatively more important in the larger particle components. In the Tropical Pacific experiment, for example, a relatively small fraction of SRP regeneration was associated with $<1 \mu \mathrm{m}$ organisms in near surface samples $(10,32 \mathrm{~m})$ in contrast to $>75 \%$ of the uptake.

The results from Arctic waters (Fig. 6) seem somewhat anomalous (with regard to the notably high SRP regeneration rates) when compared with measurements from temperate and tropical waters. It is unlikely that such high relative regeneration rates could be sustained and even in the short term would result in significant net accumulation of SRP. However, it may be noteworthy that our previous studies in this area have shown high SRP concentrations (relative to dissolved inorganic nitrogen and silicic acid) in near- surface waters at some stations (Harrison et al., 1982a). Local regeneration may have contributed to this.

\section{CONCLUSIONS}

Overall, these results provide further evidence of the importance of microplankton in nutrient recycling in coastal and oceanic waters (e.g. Harrison, 1980). Moreover, they clearly show, for phosphorus, the widespread nature of the close relationship between nutrient production (remineralization) and utilization and generally confirm the findings from studies of nitrogen recycling (e. g. Harrison, 1978; Glibert, 1982).

The methodology used in this study eliminates many of the analytical problems common to cycling studies of other nutrients (specifically nitrogen) and may be most useful in assessing nutrient regeneration and its role in the regulation of phytoplankton growth in oligotrophic ocean waters (Perry and Eppley, 1981), where analytical problems are most acute and nutrient recycling flux measurements are most urgently needed (McCarthy and Goldman, 1979; Jackson, 1980).

Acknowledgements. I would like to thank L. Hildebrand, M. Hodgson and L. Harris for expert technical assistance in analyses of SRP and particulate organic phosphorus. I am also grateful to $B$. Irwin for his assistance in collecting samples and for access to his chlorophyll data. Helpful critical comments of this manuscript were provided by W. Li, R. Smith and T. Platt. 


\section{LITERATURE CITED}

Blackburn, T. H. (1979). Method for measuring rates of $\mathrm{NH}_{4}{ }^{+}$ turnover in anoxic marine sediments, using a ${ }^{15} \mathrm{~N}-\mathrm{NH}_{4}{ }^{+}$ dilution technique. Appl. environ. Microbiol. 37: 760-765

Burmaster, D. E., Chisholm, S. W. (1979). A comparison of two methods for measuring phosphate uptake by Monochrysis lutheri Droop grown in continuous culture. J. exp. mar. Biol. Ecol. 39: 187-202

Caperon, J., Schell, D., Hirota, J., Laws, E. (1979). Ammonium excretion rates in Kaneoke Bay, Hawaii, measured by a ${ }^{15} \mathrm{~N}$ isotope dilution technique. Mar Biol. 54: 33-40

Cescon, B. S., Scarazzato, P. G. (1973). Determination of low phosphate concentrations in seawater by an isobutyl acetate extraction procedure. Limnol. Oceanogr. 18: 499-500

Duerden, F. C. (1973). Aspects of phytoplankton production and phosphate exchange in Bedford Basin, Nova Scotia. Ph. D. thesis, Dalhousie University, Halifax

Glibert, P. M. (1982). Regional studies of daily, seasonal, and size fraction variability in ammonium remineralization Mar. Biol., in press

Glibert, P. M., Lipschultz, F., McCarthy, J. J., Altabet, M. A. (1982). Isotope dilution models of uptake and remineralization of ammonium by marine plankton. Limnol. Oceanogr. 27: 639-650

Goldman, J. C., McCarthy, J. J., Peavey, D. G. (1979). Growth rate influence on the chemical composition of phytoplankton in oceanic waters. Nature, Lond. 279: 210-215

Harrison, W. G. (1978). Experimental measurements of nitrogen remineralization in coastal waters. Limnol. Oceanogr. 23: $684-694$

Harrison, W. G. (1980). Nutrient regeneration and primary production in the sea. In: Falkowski, P. G. (ed.) Primary productivity in the sea. Phenum Press, New York, pp. $433-460$

Harrison, W G. (1982). Use of isotopes. In: Capone, D., Carpenter, E. (eds.) Nitrogen in the marine environment. Academic Press, New York, in press

Harrison, W. G., Azam, F., Renger, E. H., Eppley, R. W. (1977). Some experiments on phosphate assimilation by coastal marine phytoplankton. Mar. Biol. 40: 9-18

Harrison, W. G., Platt, T., Irwin, B. (1982a). Primary production and nutrient assimilation by natural phytoplankton populatons of the Eastern Canadian Arctic. Can. J. Fish. Aquat. Sci. 39: 335-345

Harrison, W. G., Platt, T., Calienes, R., Ochoa, N. (1982b). Photosynthetic parameters and primary production of phytoplankton populations off the northern coast of Peru. In: Richards, F. A. (ed.) Coastal upwelling. Am. Geophys. Union, Washington D. C.

Holm-Hansen, O., Lorenzen, C. J., Holmes, R. W., Strickland, J. D. H. (1965). Fluorometric determination of chlorophyll. J. Cons. int. Explor. Mer 30: 3-15

Irwin, B., Harrison, W. G., Platt, T. (1982). Plankton dynamics in Bedford Basin, Nova Scotia: phytoplankton productivity experiments and nutrient measurements from February 13, 1978 until March 14, 1979. Fish. Aquat. Sci. Data Rp. No. $272,1-279$

Jackson, G. A. (1980), Phytoplankton growth and zooplankton grazing in oligotrophic oceans. Nature, Lond. 284: $439-441$

Johannes, R. E. (1964a). Uptake and release of dissolved organic phosphorus by representatives of a coastal marine ecosystem. Limnol. Oceanogr. 9: 224-234

Johannes, R. E. (1964b). Phosphorus excretion and body size in marine animals: microzooplankton and nutrient regeneration. Science, N. Y. 146: 923-924

Ketchum, B. H., Corwin, N. (1965). The cycle of phosphorus in a plankton bloom in the Gulf of Maine. Limnol. Oceanogr. 10 (Suppl.): R 148-161

Keunzler, E. J. (1970). Dissolved organic phorphorus excretion by marine phytoplankton. J. Phycol. 6: 7-13

Kuenzler, E. J., Stanley, D. W., Koenings, J. P. (1979). Nutrient kinetics of phytoplankton in the Pamilico River, North Carolina. Water Resources Research Institute Rept. No. 139: 1-163. (Univ. of N. Carolina)

Lean, D. R. S. (1973a). Movements of phosphorus between its biologically important forms in lake water. J. Fish. Res. Bd. Can. 30: 1525-1536

Lean, D. R. S. (1973b). Phosphorus dynamics in lake water Science, N. Y. 179: 678-680

Lemasson, L., Pages, A. (1981). Excretion of dissolved organic phosphorus in Tropical Brackish Waters. Estuar. coast. Shelf Sci. 12: 511-523

Longhurst, A. (1981). Biostat: an experiment in ocean plankton ecology. Cruise report for Hudson 81 (Panama to Puntarenas). Bedford Inst. Oceanogr. Report Series BI-R-81-13: 1-105

McCarthy, J. J., Goldman, J. C. (1979). Nitrogenous nutrition of marine phytoplankton in nutrient-depleted waters. Science, N. Y. 203; 670-672

Nalewajko, C., Lean, D. R. S. (1978). Phosphorus kineticsalgal growth relationships in batch cultures. Mitt. int Verein. Limnol. 21: 184-192

Nalewajko, C., Lean, D. R. S. (1980). Phosphorus. In: Morris, I. (ed.) The physiological ecology of phytoplankton. Blackwell, Oxford, pp. 191-233

Perry, M. J. (1976). Phosphate utilization by an oceanic diatom in phosphorus-limited chemostat culture and in the oligotrophic walers of the central North Pacific. Limnol. Oceanogr. 21: 88-107

Perry, M. J., Eppley, R. W. (1981). Phosphate uptake by phytoplankton in the central North Pacific Ocean. Deep Sea Res. 28: 39-49

Pomeroy, L. R. (1961). Experimental studies of the turnover of phosphate in marine environments. In: Schultz, V., Klement. A., Jr (eds.) Radioecology. Reinhold \& A. I. B. S., Washington, D. C., pp. 163-166

Redfield, A. C., Ketchum, B. H., Richards, F. A. (1963). The influence of organisms on the composition of sea-water. In: Hill, M. N. (ed.) The sea. Interscience, New York, pp. $26-77$

Rigler, F. H. (1968). Further observations inconsistent with the hypothesis that the molybdenum blue method measures orthophosphate in lake water. Limnol. Oceanogr. 13: 7-13

Ryther, J. H., Dunstan, W. M. (1971). Nitrogen, phosphorus and eutroplication in the coastal marine environment. Science, N. Y. 171: 1008-1013

Sharp, J. H. (1974), Improved analysis for 'particulate organic carbon and nitrogen' from seawater. Limnol. Oceanogr. 19: $984-989$

Strickland, J. D. H., Parsons, T. R. (1972). A practical handbook of seawater analysis. Bull. Fish. Res. Bd Can. 167 : $1-311$

Subba Rao, D. V. (1982). Size-fractionated primary production in oligotrophic waters off Costa Rica. (Abstr.) Am. Soc. Limnol. Oceanogr. Am. Meeting, Feb. 1982

Taft, J. L., Taylor, W. R., McCarthy, J. J. (1975). Uptake and release of phosphorus by phytoplankton in the Chesapeake Bay Estuary, USA. Mar. Biol. 33: 21-32 